\title{
A NOVEL EMBEDDED SYSTEM BASED ON COLD BOX DESIGN FOR THE COLD CHAIN
}

\author{
M. Mustafa SARITAS*1, Murat KOKLU², Ilker Ali OZKAN²
}

Accepted : 27/12/2017 Published: 31/12/2017

DOI: 10.18100/ijamec.2017436077

\begin{abstract}
The "cold chain" enables to remain safely the vaccines and medicines at the recommended temperature ranges during their transportation and storage period from the production site to the end user. The cold chain system is very important because of that vaccines and medicines lose their effectiveness when they exposed to a temperature above or below the limited ranges. There is no benefit of the vaccination also, if the vaccines and medicines used were ineffective; on the contrary, the vaccine can injure the applied organism. In this study, a kit based on "Arduino" was designed to ensure the continuity of the cold chain effectiveness. With this study intended was a new system designed, which enables a real time temperature and humidity control of the cold chain system in the transport ambient conditions so that it will alert when the cold chain system should have a malfunction. On the other hand, the experimental results obtained were compared which were sensitively measured with a laser thermometer capable for remote measuring. There was no difference between the results obtained and the values measured by the laser thermometer. Additionally, performance analyses of the system at the different temperatures have revealed that it is capable to stabilize the temperature value successfully.
\end{abstract}

Keywords: Control, Cold chain, Cold Box, Embedded system

\section{Introduction}

In parallel with the development of technology, the elements that facilitate human life are also tending to increase. One of these developments is called as "cold chain". Cold chain is the name given to the system which consists of the people and materials that enables an effective vaccine to deliver to the people in need only at the correct temperature ranges [1-4].

The cold chain medicines coming from the manufacturer for the end user are received by the pharmacist and the temperature of the protection cabin that contains the medicament is checked during this receiving. Each box with inappropriate temperature is marked to prevent resale of the medical products in the box. According to the result of this manual check, a new product is requested from the manufacturer if necessary, which causes loss of time and cost [5].

Even the slightest problem experienced at any step of the drug delivery process is risking patient and/or employee safety, impairing the functioning of the treatment services or financially damaging the related institution $[6,7]$.

For example, when the physician, who requests a medication purchase, should have written incorrectly the pharmaceutic form of the medication; the wrong medication to be purchased may not be consumed, or a medication in the cold chain may be stored incorrectly and it might harm the patient instead of treating him/her. Figure 1 shows the transfer steps of a vaccine from the production site to the end user in the cold chain system [8].

\footnotetext{
${ }^{1}$ Graduate School of Natural and Applied Sciences, Selcuk Uni., KonyaTURKEY

${ }^{2}$ Computer Eng., Faculty of Technology, Selcuk Uni., Konya-TURKEY

*Corresponding Author: Email: m.mustafasaritas@gmail.com
}

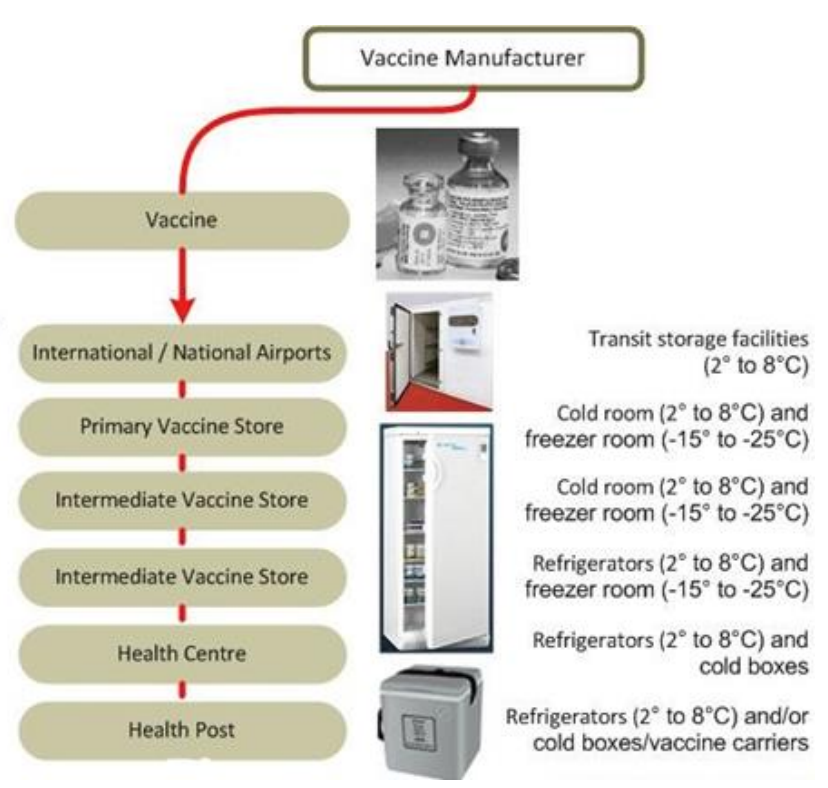

Fig. 1. Transfer steps in the cold chain system

As shown in Figure 1, in the cold chain system, besides storage after production, the special cold chain boxes and also ice packs in these boxes for cooling effect are available to provide a protective environment at the temperature ranges predetermined for the safe transfer of the medicines subject to the cold chain.

Additionally, the vaccine should be placed in a refrigerator as soon as possible at the end of the vaccine transfer process. Some medicines may be frost-resistant, so the storage conditions of the medicines should be checked $[9,10]$. Figure 2 shows an example for a cold chain box [11]. 


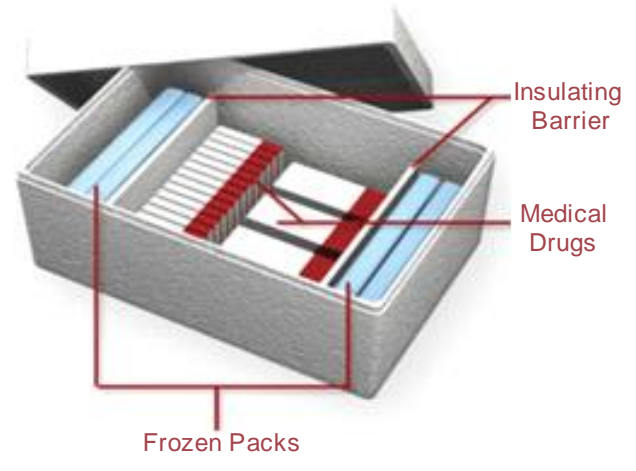

Fig. 2. Cold chain box

According to the standards World Health Organization (WHO), the temperature range specified for blood storage is between $2^{\circ} \mathrm{C}$ and $10^{\circ} \mathrm{C}$, and the researches are available to build up a cold chain according to this standard. Fidan U. designed in his study a microprocessor controlled portable thermoelectric medical device which provides the predetermined environment conditions [12].

Carrier Corp. has built up a water cooled air conditioning system of $3.5 \mathrm{~kW}$ for marine applications. This system consists of six subsystems, each with four thermoelectric modules. Each thermoelectric module measures to $13.7 \times 17.8 \mathrm{~cm}$ and has a structure with total 130 thermoelectric elements [13].

In addition, insulation of the carrier boxes has importance in the cold chain system integration. For this purpose, an aluminium sheet was placed on the bottom of the box made of foam, which is an insulative material, a piece with appropriate size was cut into the lower part of the box and the Peltier was located on this part and the sides were covered with the silicone.

An aluminium plate and a fan $12 \mathrm{~V}$ were installed on the heat surface of the Peltier to activate the Peltier cooling process. In this study performed with the Peltier was proven that the materials in the box could remain in the desired coldness degree [14].

\section{Arduino}

Arduino is a means of interacting and communicating with everyday physical parameters. Arduino is a system with significant advantages such as using open source code, having a very simple microprocessor circuit and the circuit with this system has also the necessary software package for our easy programming. Arduino projects are capable of running automatically, as well as of running by connecting to a computer.

Arduino is via USB interface connected to the computer. We are able to control a sensor with Arduino and to program the software on a computer. One of the most important reasons why Arduino is so popular is that it can use the open source code. This means that no code will be remained hidden and may be accessed these codes easily.

Programming can be performed easily by using the Arduino libraries. Analog and digital signals are processed. Systems can be designed which interact with their environment by processing the signals from the sensors. Sophisticated responses such as temperature, sound, motion, light can be provided in the environment for the designed study. Various Arduino modules and cards are also available, designed to satisfy the different needs. New projects may be developed by using these cards and modules $[15,16]$.

Arduino has some limitations as well as ease of its use: It needs electronics and programming knowledge. Furthermore, it isn't capable for heavy duties such as real time camera image transferring or signal processing [17].

\section{Materials and Method}

\subsection{Design and materials}

In the cold chain system, from the storage and transportation to the end user, stabilizing the temperature and humidity in the box is a very important requirement. In the system designed for this purpose, the temperature and humidity of the box were measured by means of sensors and a control system was established by using these measured values.

In Figure 3 is shown the layout of the box, control unit and the thermal cooling components designed for the cold chain system. According to the standards in the literature given for the refrigeration boxes/chambers, the outer structure of the box is covered with the insulating material and frozen packs, in order to increase the efficiency and performance of the cooling.

By this means, while the temperature of the medical drugs carried in the inner part is decreased suddenly, it has also established an effective insulation environment in the case of the high outdoor temperature conditions. On the inside of the box is located an Arduino based controller system and Peltier devices.

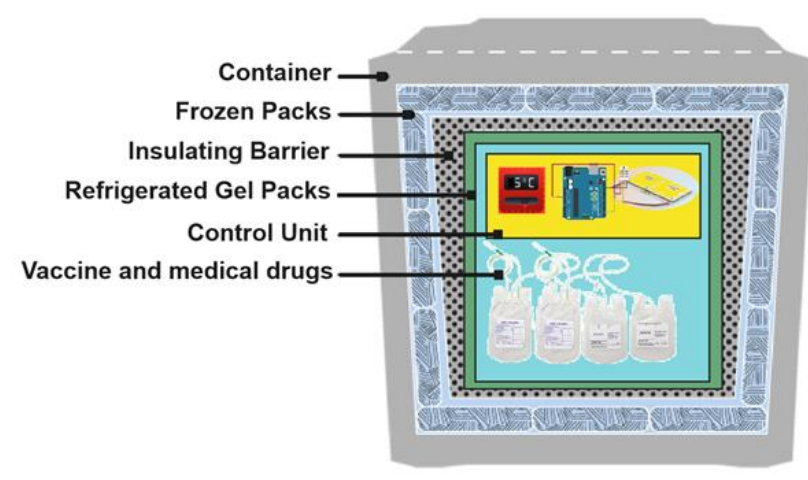

Fig. 3. Circuit overview of the cold chain box

Arduino Mega 2560 : This is an Arduino card with an ATmega2560 base (datasheet). It has 54 digital pins I/O. 14 of them are usable for the PWM outputs. It has 16 analog inputs, 4 UART (serial port), $16 \mathrm{MHz}$ crystal oscillator, USB connection, adapter input, ICSP output and a reset button. Arduino is compatible with all shields designed for Duemilanove and Diecimila. The upper version "Arduino Mega 2560" substitutes the old version "Arduino Mega" [18].

DHT22 Temperature and humidity sensor: With this module are the ambient temperature and humidity detected. Data may be received from the signal output after feeding the + and - terminals of the module. This module is quite often used in the Arduino studies. DHT22 Technical features of the DHT22: Resolution accuracy: 0.1 , humidity measurement range: 0-100\% $\mathrm{RH}$, humidity measurement accuracy: $\pm 2 \% \mathrm{RH}$, temperature measurement range: $-40 \sim 80^{\circ} \mathrm{C}^{*}$, temperature measurement accuracy: \pm 0.5 [19]

In Figure 4 is shown the circuit diagram that was designed by using the Arduino Mega 2560 and DHT22 temperature and humidity sensors. 


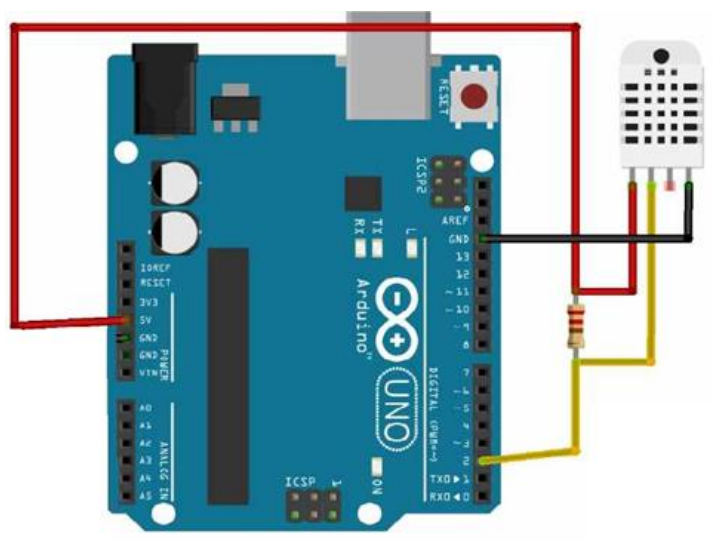

Fig. 4. Implementation diagram of the circuit

The Arduino IDE program is a software written by Arduino Corp. in the Java language, which allows you to load the codes written into the Arduino cards during programming of these cards. Arduino IDE version 1.6.3 was used when this project was being developed [20].

During the software development of the Arduino system, Arduino IDE program of the Arduino LLC Corp. was used. Figure 5 shows the program image written in the Arduino IDE.

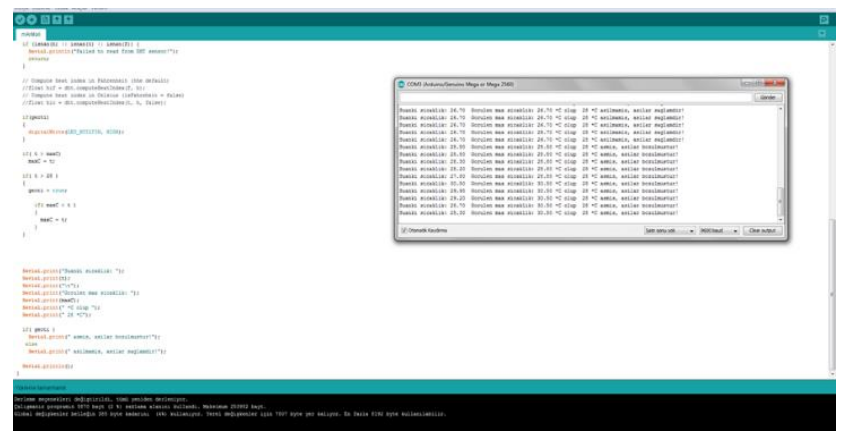

Fig. 5. Arduino IDE software program

\section{Results}

The designed and implemented system is a kit with a thermoelectric cooling system to be used for the medical transportation purposes. Thermoelectric module was used in this medicine delivery system for the cooling effect.

The system does not require any high sensitivity, since a temperature range of between $2^{\circ} \mathrm{C}$ and $8^{\circ} \mathrm{C}$ is sufficient for the medicine and vaccine transportation. Because of this, an on-off type closed loop automatic controller was used in the refrigeration system in this medical transportation. The designed two position controller generates control output for the "run" and "stop" positions only. The operation principle of the on-off controller according to the reference temperature point and to the time is shown in Figure 6 [21, 22].

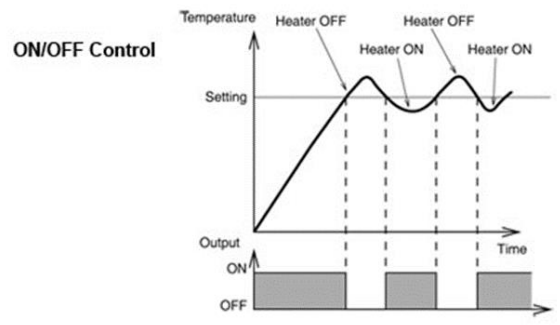

Fig. 6. Operation principle of the on-off controller
This control system was developed by researching of the related literature studies. Thermoelectric modules in the system are cooled by the Peltier. Figure 7 shows the general structure of the thermoelectric cold medicine box and the controller developed by the Arduino. The temperature setting is performed here by means of a cold box Peltier.

The sensors $S_{1}$ and $S_{2}$ located on the cold box are responsible for the measurement of the temperature value and the humidity rate in the box respectively. Cooling is performed with the on-off controller programmed with the Arduino software according to the temperature values and humidity rates measured by these sensors. Temperature and humidity values are recorded on the Arduino system every minute so that the temperature and humidity values of the cold box can be checked again when the box brought to the user place. The Arduino system may transmit the data to the mobile phone program provided via Bluetooth in order to read recorded logs and to give an instant notification.

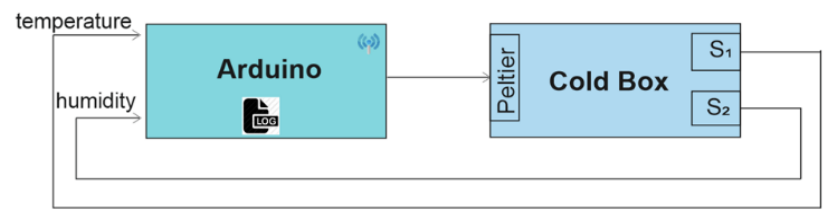

Fig. 7. General structure of the designed cold chain box and controller systems

Thanks to the project developed with Arduino Mega2560, temperature and humidity values of medicines delivered in cold chain boxes may be continuously measured and recorded. The system gives a warning, whenever the temperature value in the box goes out of the specified temperature range. By means of this warning, the risk of causing a danger by reusing the drugs which were subjected to a temperature out of range, could be eliminated. Figure 8 shows the warnings for the temperature values out of range specified, which were recorded during the application.

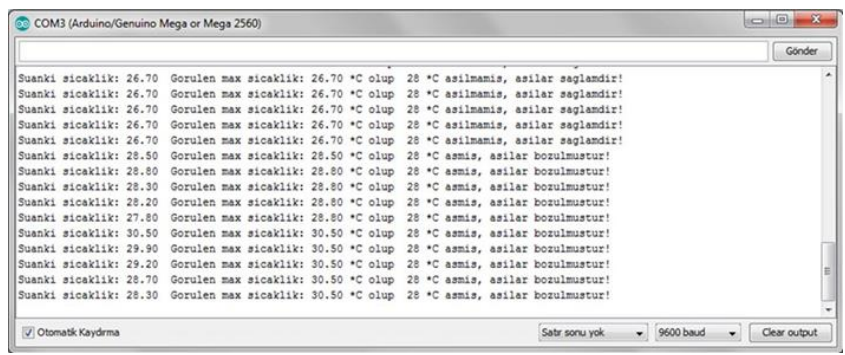

Fig. 8. Measurement results of the system and their evaluation

On the other hand, the experimental results obtained were compared which were sensitively measured with a laser thermometer capable for remote measuring. There was no difference between the results obtained and the values measured by the laser thermometer. Additionally, performance analyses of the system at the different temperatures have revealed that it is capable to stabilize the temperature value successfully.

It is mandatory to protect the vaccines and medicines at a certain temperature range so that they don't deteriorate from the production site until they reach the end user. For this reason, until the product reaches the end user, a "protection continuity" of the cold chain should be ensured throughout the storage and transportation processes.

One of the cold chain steps is using the cold boxes during transportation of the medical products. In this study, the cooling boxes developed up to now have been examined/researched in the related literature and an "Arduino" based closed-loop on-off 
controller system and data recording management software have been entegrated and designed accordingly.

The significant advantages of this new designed system than the other conventional cooling systems are its lightness, smaller sizes and lower cost. With the development of this system new designed it is predictable that the cooling and transport capacities of the medical products can be further increased and further studies may be performed in this field.

\section{References}

[1] D. M. Matthias, J. Robertson, M. M. Garrison, S. Newland, and C. Nelson, "Freezing temperatures in the vaccine cold chain: a systematic literature review," Vaccine, vol. 25, pp. 3980-3986, 2007.

[2] T. E. Odası, "Cold Chain (Soguk Zincir)," Trabzon Ecazılar Odası, Trabzon2017.

[3] S. Techathawat, P. Varinsathien, A. Rasdjarmrearnsook, and P. Tharmaphornpilas, "Exposure to heat and freezing in the vaccine cold chain in Thailand," Vaccine, vol. 25, pp. 1328-1333, 2007/01/26/ 2007.

[4] C. Nelson, P. Froes, A. M. V. Dyck, J. Chavarría, E. Boda, A. Coca, et al., "Monitoring temperatures in the vaccine cold chain in Bolivia," Vaccine, vol. 25, pp. 433-437, 2007/01/05/ 2007.

[5] I. University. (2017, 06.05.2017). Istanbul Faculty of Medicine Cold Chain Drug Control Instruction. Available: http://istanbultip.istanbul.edu.tr/wp-content/uploads/2014/02/ So\%C4\%9Fuk-Zincir-\%C4\%B0la\%C3\%A7lar\%C4\%B1n-Kontrol\% C3\%BC-Talimat\%C4\%B1.pdf

[6] F. D. Acu, A. A. Adedeji, J. S. Esan, and O. G. Odusanya, "Live viral vaccine potency: an index for assessing the cold chain system," Public Health, vol. 110, pp. 325-330, 1996/11/01/ 1996.

[7] E. Weir and K. Hatch, "Preventing cold chain failure: vaccine storage and handling," Canadian Medical Association Journal, vol. 171, pp. 1050-1050, 2004.

[8] (2017). Cold Chain - Logistics Operational Guide (LOG) - Digital Logistics Capacity Assessments. Available: http://dlca.logcluster.org/display/LOG/Cold+Chain

[9] A. İ. S. Müdürlüğü. (2017, 06.05.2017). İlaç Güvenliği Rehberi. Available:

http://www.asm.gov.tr/UploadGenelDosyalar/Dosyalar/143/B\%C4\% B0LG\%C4\%B0/13_04_2017_11_31_27.pdf

[10]S. Devrani, S. Pandey, S. Chaturvedi, K. Sankar, S. Patil, and K. Sridhar, "Design and Analysis of an Efficient Vaccine Cold Chain Box," in ASME 2016 International Mechanical Engineering Congress and Exposition, 2016, pp. V003T04A018-V003T04A018.

[11]D. G. F. v. S. C, "Verimlilik Gözlemlerinde Eczacılık Hizmetleri Ve Medikal Depo Boyutu," Ankara2017.

[12]U. Fidan, "Mikrodenetleyici Kontrollü Taşınabilir Termoelektrik Tip Kiti Cihaz Tasarımı Ve Uygulaması, Yüksek Lisans Tezi (yayımlanmış), Gazi Üniversitesi Fen Bilimleri Enstitüsü," Elektronik Bilgisayar Ĕgitimi, Ankara, 2000.

[13]H. Çakır, "Güneş Piliyle Elde Edilen Elektrik Enerjisinin Termoelektrik Soğutmada Kullanılması," Yüksek Lisans Tezi (yayımlanmıs), Zonguldak Karaelmas Üniversitesi Fen Bilimleri Enstitüsü, Makine Eğitimi, Zonguldak, vol. 1, 2006.

[14] Alpin. (2017). Portatif, küçük bir buzdolabı yapımı - Kendin Yap Proje Yapımı Sitesi. Available: http://www.kendinyapsitesi.com/proje.asp?id=1384

[15]H. Dalkılıç and M. H. Özcanhan, "Gömülü Sistem Tabanlı Model Mobil Aracın Akıllı Telefonla Uzaktan Kontrolu," XVIII. Akademik Bilişim Konferansl- $-A B$, vol. 30, 2016.

[16]C. Taşdemir, "Arduino Analog-Dijital-Sensörler-HaberleşmeProjeler," Türkiye Dikeyeksen Yayıncllık, vol. 1, p. 67, 2012.

[17]K. Kayaalp and S. Özkorucuklu, "ARDUINO TEKNOLOJISi KULLANILARAK TARLA IÇİN RADYASYON KAPI KONTROLÜ TASARIMI," SDU International Journal of Technological Science, vol. 7, 2015.

[18](2017, 07.05.2017). What is Arduino Mega 2560? . Available: http://arduinoturkiye.com/arduino-mega-2560-nedir/

[19](2017, 07.05.2017). DHT22 Temperature and Humidity Sensors. Available: DHT22 Isı ve Nem Sensörü

[20] Arduino.cc. (2017, 10.05.2017). Arduino - Software IDE. Available: https://www.arduino.cc/en/main/software

[21]C. T. Chen and C. Hwang, "Optimal on-off control for fed-batch fermentation processes," Industrial \& engineering chemistry research, vol. 29, pp. 1869-1875, 1990.
[22](2017, 12.05.2017). What is On/Off Control. http://www.coulton.com/What_is_On_Off_Control.html 